Clemson University

TigerPrints

$1-2020$

The effect of professional development on elementary science teachers' understanding, confidence, and classroom implementation of reform-based science instruction

Jennifer L. Maeng

Brooke A. Whitworth

Randy L. Bell

Donna R. Sterling

Follow this and additional works at: https://tigerprints.clemson.edu/teach_learn_pub

Part of the Science and Mathematics Education Commons 


\title{
The effect of professional development on elementary science teachers' understanding, confidence, and classroom implementation of reform-based science instruction
}

\author{
Jennifer L. Maeng ${ }^{1} \odot \mid$ Brooke A. Whitworth ${ }^{2} \odot \mid$ Randy L. Bell ${ }^{3} \mid$ \\ Donna R. Sterling ${ }^{4 \dagger}$
}

${ }^{1}$ Curriculum, Instruction, and Special Education, Curry School of Education and Human Development, University of Virginia, Charlottesville, Virginia

${ }^{2}$ Department of Teacher Education, University of Mississippi, Oxford, Mississippi ${ }^{3}$ College of Education, Oregon State University, Corvallis, Oregon

${ }^{4}$ College of Education and Human Development, George Mason University, Fairfax, Virginia

\section{Correspondence}

Jennifer Maeng, Curry School of Education and Human Development, University of Virginia, 417 Emmet Street South, Charlottesville, VA 22904.

Email: jlc7d@virginia.edu

\section{Funding information}

U.S. Department of Education Investing in Innovation (I3) grant program,

Grant/Award Number: \#U396B100039

\begin{abstract}
Through a randomized controlled trial, this mixed-methods study evaluated changes in elementary science teachers' understandings, confidence, and classroom implementation of problem-based learning (PBL), inquiry, and nature of science (NOS) instruction following participation in a professional development (PD) as well as the components of the PD that teachers perceived facilitated these changes. Results indicated that following the PD, treatment teacher $(n=139)$ understandings of and confidence for teaching inquiry, NOS, and PBL were significantly greater than control teachers $(n=98)$ after controlling for preunderstandings and confidence. The effect sizes were large. Treatment teachers also incorporated significantly more PBL, inquiry, and NOS into their instruction. Modeling, microteaching with feedback and reflection, and inclassroom coaching facilitated teachers' confidence, understanding, and intention to implement the reform-based practices they learned. Implications for the understanding of the relationship between knowledge, confidence, and practice as well as elementary science teacher PD design are discussed.
\end{abstract}

KEYWORDS

elementary, RCT, reform-based instruction 
The Framework for K-12 Science Education identifies scientific literacy as a principal goal of science education (National Research Council [NRC], 2012). Yet, achieving scientific literacy is complex and challenging. It requires students to be proficient at knowing, using, and interpreting scientific explanations of the natural world, generating and evaluating evidence, understanding the nature of and how scientific knowledge is developed, and participating productively in scientific practice and discourse (NRC, 2007). Research suggests students develop scientific literacy through student-centered reform-based instruction that promotes students' conceptual understanding and use of science concepts, provide students opportunities to learn about and practice science inquiry and the skills necessary to conduct inquiry, and includes explicit instruction about the nature of scientific knowledge (e.g., Lederman, 2007; NRC, 2012).

Such instruction necessarily places the teacher in the role of facilitator of learning (NRC, 2012). Indeed, a number of studies suggest the effectiveness of reform-based science instruction on students' achievement and attitudes toward science is influenced by teachers' understandings, and practices (Kanter \& Konstantopoulos, 2010; Roth et al., 2011). Yet, elementary teachers often do not have backgrounds in science and many do not teach science daily (Banilower et al., 2018), both of which relate to personal science teaching efficacy (confidence; Ramey-Gassert, Shroyer, \& Staver, 1996). Therefore, the goal of this mixed-methods randomized controlled trial was to determine if participation in statewide professional development (PD) program, the design of which was aligned with key components of effective PD (e.g., Desimone, 2009; Loucks-Horsley, Stiles, Mundry, Love, \& Hewson, 2010; Voogt et al., 2015), improved elementary teachers' confidence, understandings, and classroom implementation of reform-based science instruction (e.g., inquiry).

\section{1 | REFORM-BASED SCIENCE INSTRUCTION}

The PD that served as the context of the present investigation emphasized three reform-based practices identified in the literature as supporting the development of students' scientific literacy and increasing student science achievement: problem-based learning (PBL), inquiry, and nature of science (NOS; e.g., Akerson \& Abd-El-Khalick, 2003; Hmelo-Silver, 2004; NRC, 2012; Roth et al., 2011). These three constructs were selected because PBL can be used as an overarching structure for explicit NOS and inquiry instruction (e.g., Maeng, Bell, St. Clair, Gonczi, \& Whitworth, 2018; Moutinho, Torres, Fernandes, \& Vasconcelos, 2015).

In PBL, students investigate a meaningful, real-world problem and present solutions to the problem based on their findings (Sterling, 2007). PBL incorporates an authentic context, problems with multiple or divergent solutions, inquiry experiences, and collaboration among students (Hmelo-Silver, 2004). Additionally, it facilitates students' real-world application of scientific knowledge and methods through student-centered instruction (Chin \& Chia, 2004). When inquiry investigations are embedded within PBL units, students are able to investigate questions, analyze data, and synthesize their findings from multiple investigations to help solve the overarching PBL problem. Asking questions, planning and carrying out investigations, analyzing and interpreting data, constructing explanations, and obtaining, evaluating, and communicating information constitute the elements of scientific inquiry (Martinez, Borko, \& Stecher, 2012).

PBL also has the potential to provide opportunities for teachers to explicitly address NOS in instruction (Maeng et al., 2018). NOS instruction involves explicitly teaching students the values and assumptions essential to scientific knowledge development. The science education community agrees on the importance of NOS instruction and several NOS ideas appropriate to teach K-12 students (Bell, Mulvey, \& Maeng, 2016; Lederman \& Lederman, 2014; McComas, Clough, \& Almazroa, 1998; NGSS Lead States, 2013). These ideas include that scientific knowledge is empirical, simultaneously reliable and tentative, based on observation and inference. In addition, scientific theories and laws are different kinds of knowledge, and many methods are employed to develop scientific knowledge. Researchers also agree effective NOS instruction makes these ideas explicit to students (e.g., Abd-El-Khalick \& Akerson, 2004; Akerson \& Hanuscin, 2007; Bell, Abd-El-Khalick, \& Lederman, 1998). Including explicit NOS 
instruction in the context of PBL units has the potential to facilitate students' consideration of the authenticity of the problem and how their investigations are similar to the work of practicing scientists (e.g., Maeng et al., 2018; Moutinho et al., 2015).

\section{2 | CHANGING TEACHERS' CONFIDENCE, UNDERSTANDINGS, AND PRACTICE}

Such reform-based approaches to science instruction represent dramatic shifts from traditional instruction (LoucksHorsley \& Matsumoto, 1999) and previous attempts to prepare teachers to teach inquiry and NOS report mixed results (e.g., Lederman, 2007; Roehrig \& Luft, 2004; Schneider, Krajcik, \& Blumenfeld, 2005). Significant barriers to the implementation of reform-based science instruction among elementary teachers are confidence, content knowledge, and knowledge of how to implement reforms-based practices (Lakshmanan, Heath, Perlmutter, \& Elder, 2011; Ramey-Gassert et al., 1996; Sandholtz \& Ringstaff, 2014). Other barriers to reform-based instruction are institutional (e.g., standardized testing) and technical (e.g., lack of resources or materials; e.g., Arora, Kean, \& Anthony, 2000; Bauer \& Kenton, 2005; Johnson, 2006, 2007; Keys \& Bryan, 2001).

Bandura's (1986) Social Learning Theory describes confidence or personal self-efficacy as a component of selfefficacy. The science education literature is replete with studies on the factors that influence elementary teachers' confidence in their ability to effectively teach science (i.e., personal science teaching efficacy; e.g., Ramey-Gassert \& Shroyer, 1992). Factors that contribute to high levels of confidence for science teaching include strong science background, desire to implement reform-based instruction, and elementary science teaching experience (e.g., Cantrell, Young, \& Moore, 2003; Enochs, Scharmann, \& Riggs, 1995; Mulholland, Dorman, \& Odgers, 2004; Ramey-Gassert et al., 1996). Importantly, a number of studies suggest elementary teachers' confidence may influence their reform-based instructional practices (e.g., Lakshmanan et al., 2011; Ramey-Gassert et al., 1996; Sandholtz \& Ringstaff, 2014).

In addition to confidence, teachers' reluctance to implement reform-based science instruction may also be related to their knowledge of science content, understandings of NOS, and/or familiarity of pedagogical approaches (e.g., inquiry, PBL) that support reform-based instruction (e.g., Johnson, 2006, 2007; Lederman, 2007; LoucksHorsley et al., 2010; Supovitz \& Turner, 2000). For example, effective NOS and inquiry instruction does not come easily for most teachers (e.g., Akerson \& Abd-El-Khalick, 2003; Bell et al., 1998; Lederman, 2007; Lederman, Lederman, Kim, \& Ko, 2012). Some teachers conflate inquiry instruction with hands-on instruction and teaching NOS with inquiry and process skills (Crawford, 2000; NRC, 2000). Still, other teachers do not recognize that NOS instruction must explicitly address targeted NOS conceptions through student reflection and discussion to be effective (e.g., Bell, Blair, Crawford, \& Lederman, 2003; Hanuscin, Akerson, \& Phillipson-Mower, 2006; Khishfe, 2008; Scharmann, Smith, James, \& Jensen, 2005; Schwartz, Lederman, \& Crawford, 2004). In contrast to what is known about effective science teaching, Trygstad, Smith, Banilower, and Nelson (2013) note that 40\% of elementary teachers believe ideas should be explained to students before students consider the evidence. In addition, over $50 \%$ of elementary teachers endorse the idea that hands-on activities should be used primarily for reinforcement and over $80 \%$ agree that students should be given definitions for new vocabulary at the beginning of instruction. "These inconsistencies in teacher pedagogical beliefs represent a potential barrier" to reform-based science instruction (Trygstad et al., 2013, p. 5).

\section{3 | EFFECTIVE PD}

Given these challenges, the science education community is committed to designing and implementing PD that improves teachers' knowledge and classroom implementation of reform-based pedagogy (Johnson, 2006, 2007; LoucksHorsley et al., 2010; Supovitz \& Turner, 2000). However, changing teachers' practice is a time-consuming and complex 
process (Desimone, 2009; Lotter, Harwood, \& Bonner, 2007). Previous research suggests that PD aligned with a situated learning perspective may be effective at changing teachers' beliefs and practices (e.g., Bell et al., 2016; Maeng et al., 2018; Voogt et al., 2015). Situated learning theory proposes that learning occurs best in the context in which it will be used and that interactions between individuals support learning (Lave \& Wenger, 1991; Orgill, 2007).

Consistent with situated learning theory, the literature indicates that for science teacher PD to elicit desired changes in teachers' practices, it should be sustained and ongoing, coherent, and support teachers in their classroom environments through expert coaching (e.g., D. K. Cohen \& Hill, 2000; Johnson, Kahle, \& Fargo, 2007; Supovitz, Mayer, \& Kahle, 2000). Sustained and ongoing refers to both the total hours of PD and the amount of time over which the PD occurs (Desimone, 2009). Coherence (Birman, Desimone, Porter, \& Garet, 2000) and expert coaching (Loucks-Horsley et al., 2010; Luft et al., 2011) facilitates teachers' implementation of new teaching strategies. Coherent PD builds on previous activities, is followed with future PD activities, is consistent with teacher goals, and draws teachers into dialogues about their experiences with other teachers and administrators in their own school (Birman et al., 2000). Providing teachers with expert coaching is one way to continue the PD through a program of teacher learning and support teachers as they attempt new practices (Grierson \& Woloshyn, 2013; Luft et al., 2011).

Effective PD also acknowledges teachers' current practices, is content-focused, provides teachers with opportunities for active learning, and fosters collective participation (Desimone, 2009; Loucks-Horsley et al., 2010; Supovitz \& Turner, 2000). Content focus refers to the ability of PD to support teachers in understanding subject matter, learners and learning, and teaching methods (Loucks-Horsley \& Matsumoto, 1999). It is important for PD to focus on content and methods to increase teacher learning and skills (Birman et al., 2000; Desimone, 2009; Kennedy, 1999; Loucks-Horsley \& Matsumoto, 1999). Active learning during PD can take numerous forms including observing other teachers, observing or videotaping lessons with opportunities for reflection, reviewing and analyzing student work, leading or participating in discussions, developing lesson plans, or practicing a teaching method in a group setting (i.e., microteaching; Desimone, 2009). The presence of teachers from similar schools, department, subject areas, or grade levels, or collective participation, can enable conversations and discussions that enhance teacher learning through increased active learning and coherence (Birman et al., 2000; Borko, 2004; LoucksHorsley \& Matsumoto, 1999). Other advantages of collective participation include the opportunity to develop a professional learning community and for teachers to discuss changes to their curriculum as a group (Birman et al., 2000). These elements of effective PD are well-aligned with a situated learning perspective (e.g., Voogt et al., 2015).

\section{4 | PURPOSE}

There is a clear understanding about the importance of incorporating NOS, inquiry, and PBL into science instruction. Likewise, there is sufficient research on the role confidence, content knowledge, and knowledge of reform-based practices play in elementary teachers' implementation of reform-based practices. Also, research is clear that effective PD has the potential to change teachers' practices. However, little is known about how sustained, content-based, coherent PD that incorporates a coaching component and is built on collective participation specifically impacts elementary teachers' understandings, confidence, and classroom implementation of PBL, inquiry, NOS. Thus, the purpose of this investigation was to characterize changes in elementary teachers' understanding, confidence, and classroom implementation of PBL, NOS, and inquiry instruction following a PD experience that incorporated key characteristics of effective PD. Unique from previous studies, an RCT design allowed us to make causal claims about the efficacy of the PD in supporting changes in teachers' understandings, confidence, and practices. The following research questions guided the investigation:

1) How did teachers' understandings of PBL, inquiry, and NOS instruction change as a result of participation in the PD and how did their understandings compare to those of control group teachers? 
2) How did teachers' confidence in implementing PBL, inquiry, and NOS change after participation in the PD and how did these teachers' confidence compare to those of control group teachers?

3) How did treatment teachers' classroom implementation of PBL, inquiry, and NOS compare to those of control group teachers?

4) How much variance in teacher implementation of PBL, inquiry, and NOS can be explained by confidence, understandings, and PD participation?

5) What components of the PD did teachers perceive as facilitating changes in their understandings, confidence, and practices?

\section{5 | METHODS}

This explanatory mixed-methods study (Creswell \& Plano Clark, 2011) employed a cluster RCT design to evaluate changes in participants' confidence, knowledge, and practices as a result of the PD compared to a control group. Quantitative data from pre/post/year-end surveys and classroom observations were supported with qualitative data from open-ended survey and interview responses. An inductive approach was employed to ascertain participants' perceptions of the key components of the PD they perceived as facilitating changes in their confidence, understanding, and practices.

\section{1 | Participants/context}

For each of the two cohorts, school teams (ranging in size from two to six members) of 4th through 6th-grade teachers from a mid-Atlantic state were randomized via straight random assignment into treatment or control groups. Of the 115 school teams that applied across the two cohorts, 58 school teams $(n=160)$ were randomized into the treatment condition and 57 school teams $(n=157)$ were randomized into the control condition. Teams randomized into the control condition were eligible to participate in the PD the following year; however, if they elected to participate in the PD after their control year, they were not included in the treatment team analysis for the purposes of this study.

The teams included in the analyses were the 54 teams (93\%) and 40 teams (70\%) of control teams retained through the end of the study. On average, schools in the treatment condition were comprised of approximately 8.4\% (standard deviation $[S D]=12.7)$ English Language Learners, 47.5\% $(S D=25.1)$ receiving free or reduced-price meals, and $54.4 \%(S D=28.7)$ non-White students. Similarly, the demographics of schools in the control condition were comprised of approximately 8.9\% (SD = 16.7) English Language Learners, $50.2 \%(S D=24.1)$ receiving free or reduced-price meals, and $48.7 \%(S D=28.7)$ non-White students. Independent $t$ tests indicated no significant difference between treatment or control school demographics.

Included in the 54 treatment teams were 139 teachers. The 40 control teams included 98 teachers. Treatment teachers ranged in experience from 0 to 41 years with an average of 11.8 years $(S D=8.8)$. Control teachers ranged in experience from 0 to 39 years with an average of 12.4 years $(S D=8.8$ ). Demographic data (Table 1$)$ were selfreport and all participants were assigned a participant ID.

The goal of the investigation was to assess the impact of all of the PD components on teachers' knowledge, confidence, and implementation of target constructs; therefore, we defined the control group teachers as not participating in any of these PD activities. Treatment teachers participated in an intensive 4-week summer institute with academic year follow-up and coaching, while control teachers received no support from this PD program. Table 2 identifies how the activities in the year-long PD were aligned with the characteristics of effective PD. The 4-week (152 contact hours) summer institute was implemented at four universities and was coplanned and facilitated by teams of university science educators, scientists, engineers, and science and mathematics specialists. 
TABLE 1 Participant demographic data

\begin{tabular}{|c|c|c|c|c|c|c|c|}
\hline \multirow[b]{2}{*}{ Condition } & \multicolumn{2}{|l|}{ Gender } & \multicolumn{5}{|c|}{ Race/ethnicity } \\
\hline & Female (\%) & Male (\%) & White (\%) & Black (\%) & Hispanic (\%) & Asian (\%) & Native American (\%) \\
\hline Treatment $(n=139)$ & $116(85.9)$ & 19 (14.1) & $102(75.6)$ & $29(21.5)$ & $2(1.5)$ & $1(0.7)$ & $1(0.7)$ \\
\hline Control $(n=98)$ & $80(85.1)$ & 14 (14.9) & $73(78.5)$ & 17 (18.3) & $2(2.2)$ & $1(1.1)$ & $0(0)$ \\
\hline
\end{tabular}

Note: Not all teachers reported gender and ethnicity information. Percentages reported are for respondents to each demographic question.

\subsubsection{Week 1}

During the first week, teachers participated inactive, content-focused PD around NOS and inquiry within the context of PBL. In the first 2 days, the facilitators modeled how PBL could be used as a context for inquiry. The teachers took on the role of a fifth-grade student and received a News Flash that identified the problem to be solved, (i.e., the Governor needed help determining how to reach energy independence by the year 2020 because of brownouts in the state). The teachers learned they would need to develop and present an energy plan that included "energy sources available in regions of [the state] so we don't have to rely on outside sources, discusses the feasibility and efficiency of each source, and analyzes the environmental impact of the energy extraction, production, and use" to the Governor. The teachers brainstormed a list of questions needed they needed to answer to address the overarching question: "How can our state become energy independent?" As teachers shared their

TABLE 2 Alignment of the components of effective PD with PD activities

\begin{tabular}{|c|c|c|}
\hline PD timeframe & PD activities & $\begin{array}{l}\text { Corresponding effective PD } \\
\text { components }\end{array}$ \\
\hline Week 1 & $\begin{array}{l}\text { Teachers attend in school teams } \\
\text { Instruction on inquiry, NOS, and PBL situated within } \\
\text { content } \\
\text { Introduced to coaches } \\
\text { Collaborative development of PBL unit for camp } \\
\text { Content aligned to state Standards of Learning (SOLs) }\end{array}$ & $\begin{array}{l}\text { Collective participation } \\
\text { Active learning, content-focused, } \\
\text { coherence }\end{array}$ \\
\hline \multicolumn{3}{|l|}{ Weeks 2 and 3} \\
\hline \multirow[t]{2}{*}{ Camp week } & $\begin{array}{l}\text { Collaborative PBL unit aligned with SOLs } \\
\text { Teachers practice new pedagogy with students during } \\
\text { camp }\end{array}$ & $\begin{array}{l}\text { Coherence } \\
\text { Active learning }\end{array}$ \\
\hline & $\begin{array}{l}\text { Teachers receive feedback from facilitators, peers, and } \\
\text { coaches }\end{array}$ & Expert coaching \\
\hline \multirow[t]{3}{*}{ Module week } & $\begin{array}{l}\text { Modules on integrating math, literacy/discourse, } \\
\text { technology, and engineering }\end{array}$ & Content-focus \\
\hline & Field work and content instruction with researchers & Active learning \& content-focused \\
\hline & Content aligned to SOLs & Coherence \\
\hline \multirow[t]{4}{*}{ Week 4} & $\begin{array}{l}\text { Teachers work in school teams to develop PBL unit to } \\
\text { teach during academic year }\end{array}$ & Collective participation \\
\hline & Teachers work with coaches to plan PBL unit & Active learning \\
\hline & Teachers work with principals and science coordinators & Coherence \\
\hline & & Expert coaching \\
\hline \multirow[t]{4}{*}{ Academic year } & Implementation of PBL unit & Active learning \\
\hline & Coaching sessions (22.5 hr) & Sustained, on-going \\
\hline & Follow-up sessions ( $14 \mathrm{hr}$ ) & Coherence \\
\hline & Attendance at state science teachers' conference & Expert coaching \\
\hline
\end{tabular}

Abbreviations: NOS, nature of science; PBL, problem-based learning; PD, professional development. 
questions, they categorized the questions by similar topics. The facilitators then introduced the idea of a question map and shared one they had developed using the same question.

The facilitators selected one of the questions to focus on, "How is one type of energy transformed into another type?" Teachers completed the Know and Want to Know portions of a KWL chart. Next, they conducted research on energy forms, sources, and transfer through a reading, anticipation guide, and jigsaw with teachers in their group. After sharing this information, the group received an Update from the Governor's Office. The update shared there was a tool that could transform energy and investigating how it works and what it does might help them to solve their problem. Teachers were then asked to explore the device, record observations, and think about how the object might work or what it might do. (The device was a radiometer, but they were not told this.) The teachers designed an experiment using the Four-Question Strategy (Cothran, Geiss, \& Rezba, 2000) to answer the question "How does this device work?" Teachers were given a variety of materials they could use in their investigation and experimented with their group's chosen independent variable (light, heat, angle of light/heat, etc.). The groups then shared their results, issues they encountered, and discussed what further information was needed to solve the overarching problem.

Following this, the teachers stepped out of their role as 5th graders and debriefed the experience with the facilitators. First, the facilitators asked teachers to think about the features of the lesson structure that helped them as learners and how the investigation allowed them to learn information that would help them to answer the overarching question. Then, teachers debriefed the activities in terms of their role as a teacher. They discussed the aspects of the activities they liked and compared this approach to their current approaches to teaching science, specifically asking the teachers to consider the ways in which it was different from their current practice. Then, teachers were introduced to a formal definition of PBL "Students solving a meaningful problem with multiple solutions over time, as a scientist would in a real-world context. The problem and context must be meaningful to students." and several key characteristics of PBL (e.g., overarching problem question, scenario, student role, culminating activity). They were also introduced to a formal definition of inquiry "students asking questions, collecting and analyzing data, and using evidence to solve problems" (Maeng \& Bell, 2012, p. 3). The teachers then discussed how the investigation they participated in using the Four-Question Strategy aligned with this definition of inquiry.

The next day, teachers were introduced to NOS. First, they completed a card sort in which they sorted statements about science and NOS into agree, disagree, and not sure piles. This preassessment set the framework for learning about NOS throughout the summer component of the PD; each teacher had their own set of cards and they were asked to resort these cards at various points during the summer to assess if their ideas changed. Following the card sort, teachers engaged in an investigation related to the PBL scenario from the previous day. Facilitators then led a discussion to make this link explicit and to explicitly discuss the NOS ideas embedded in the investigation from this day and from the radiometer investigation (see Maeng et al., 2018). The facilitators then introduced the NOS ideas present in the state Standards (http://www.doe.virginia.gov/testing/sol/standards_docs/ science/index.shtml\#2010).

Throughout the rest of the first week, facilitators built on these initial experiences to help teachers further understand PBL, NOS, and inquiry and what science instruction that included these constructs would look like in the classroom. The teachers also coplanned a PBL unit to be taught during a 2-week summer camp for 4-6th-grade students. Teachers developed their question map as a whole group, then assigned questions to individual teachers or teams of teachers who planned lessons for that portion of the summer camp. Scientists were present to aid teachers in their content understanding.

\subsection{2 | Weeks 2 and 3}

Teachers were split into two groups during each of these weeks. One group of teachers taught the PBL they had developed to the students in the summer camp. The teachers in this group who were not teaching observed 
using various observation protocols (i.e., inquiry and discourse, hands-on and management, PBL and connections, NOS and misconceptions). Every teacher had the opportunity to use each protocol at least once. The recorded information was used at the end of every camp day to debrief the work of the teachers who taught.

The other group of teachers not working with the campers continued with active, content-focused PD with scientists and experience modules. They learned how mathematics, engineering, technology, discourse, and literacy could be integrated into a PBL unit and had an opportunity to begin brainstorming themes for the PBL unit they would develop.

Teachers also engaged in field research experience with scientists for 2 or 3 days during this week. Throughout these experiences, teachers learned content, engaged in collecting data and answering research questions, and thinking about NOS (e.g., how their work paralleled the work of scientists). These opportunities provided rich experiences upon which teachers could build a deeper understanding of science content and the approaches scientists use to develop knowledge. During the third week, the two groups switched.

\subsection{3 | Week 4}

Teachers used this week to develop the PBL unit they would teach during the upcoming academic year. Teachers worked with scientists, math specialists, their classroom coaches, and facilitators as they planned their unit. During this week the teachers' principals and/or division science coordinators attended a morning session to learn about what the teachers experienced and they spent the afternoon with teachers to learn about their PBLs and the support they might need during the academic year. On the final day of the summer institute, teachers shared a brief overview of the PBL unit they were planning with the group. Throughout the 4 weeks, coaches attended 3 days to meet, work with, and support teachers as they developed and planned their units.

\subsection{4 | Academic year}

During the academic year, teachers participated in at least $14 \mathrm{hr}$ of follow-up sessions and attended the annual state science teachers' conference. Coaches worked with teachers $22.5 \mathrm{hr}$ across the academic year to coplan, coteach, observe, promote reflection, and provide feedback on teachers' science instruction. Coaches were experienced, often recently retired, elementary teachers. Before coaching, they received $16 \mathrm{hr}$ of PD. During the PD, they reviewed the goals for teachers and their role expectations, learned strategies for supporting teachers in implementing PBL, inquiry, and NOS, and learned approaches for providing formative feedback to teachers using a coaching cycle aligned with Cognitive Coaching (Costa \& Garmston, 2002; Knight, 2009). Coaches also attended the summer institute where they developed an initial rapport with the teachers with whom they would be working during the academic year. Thus, the PD was well-aligned with a situated learning perspective (e.g., Lave \& Wenger, 1991) and the components identified in the PD literature as supporting teacher change (e.g., Desimone, 2009; Loucks-Horsley et al., 2010; Voogt et al., 2015).

\section{2 | Data collection and analysis}

Data for all treatment and control teachers consisted of the PBL, inquiry, and NOS Confidence and Knowledge (PINCK) Survey, follow-up interviews of a subset of teachers, videotaped classroom observations, and observation forms. As the unit of randomization was the school team, analysis of differences in treatment and control teacher confidence, understandings, and practices occurred at this level. 


\subsection{1 | PINCK survey}

PINCK Surveys were administered pre-/post-, and year-end to elicit teachers' understanding of key constructs (PBL, inquiry, and NOS instruction), their confidence, and perceptions of the effectiveness of the PD through Likertscale and open-ended items.

\section{Understandings}

While validated instruments exist for assessing understandings of NOS and scientific inquiry (e.g., Lederman, Abd-El-Khalick, Bell, \& Schwartz, 2002; Lederman \& Lederman, 2014), none of these proved appropriate for the present investigation. For example, the set of tenets that comprised the PD's operational definition of NOS (scientific knowledge is tentative, empirical, and influenced by social/cultural factors) is only a subset of those addressed in Lederman's et al. (2002) instrument. Further, it was critical that the instruments provide an opportunity for participants to explicate their understandings of PBL, NOS, and inquiry through descriptions of student and teacher behaviors during lessons that emphasize each of the target constructs. Finally, it was important to avoid over-burdening the participants with multiple instruments that contained writing-intensive items not related to the content of the PD. To address these issues, the researchers created a single instrument (PINCK) informed by existing instruments (e.g., Lederman et al., 2002; Schwartz, Lederman, \& Lederman, 2008), that asked participants to define and to describe what teachers/students do in a lesson that emphasizes PBL, inquiry, and NOS, respectively. Content validity for the PINCK were supported by rounds of review by a panel of three experts with backgrounds in science education and research evaluation. Each round of review informed revisions to the instrument, which in turn was reviewed again by the panel. Rounds of review/revision continued until the panel was satisfied that the instrument provided an effective measure of the three target constructs. Finally, member-check interviews of a subset of respondents during the study provided further validation of PINCK responses.

Teachers' pre-, post-PD, and year-end definitions and descriptions of PBL, NOS, and inquiry instruction in the classroom were analyzed using systematic data analysis (Miles \& Huberman, 1994) and a multipart rubric validated for face and content validity (Tables 3 and 4; Figure 1). Teachers' responses were coded as not aligned, partially aligned, and fully aligned for definitions and implementation of PBL, inquiry, and NOS instruction. These categories Raters also coded teachers' understanding that effective NOS instruction should be explicit. Two raters independently coded each participant's open-ended responses related to PBL, inquiry, and NOS and inter-rater agreement were established ( $90 \%$ ) by comparing independent analysis across approximately $30 \%$ of the data. Discrepancies in coding were resolved through discussion. Examples of coded responses are provided in the Supporting Information Methods and Figure 2.

\section{Confidence and PD effectiveness}

PINCK Surveys also assessed teachers' confidence and perceptions of the effectiveness of the PD through Likertscale and open-ended items. For Likert-scale items, the scale ranged from 1 (not very proficient) to 5 (highly proficient). Teachers were also asked to indicate the confidence with which they implement these constructs into their science instruction. Common to the post- and year-end PINCK Surveys were additional Likert-scale and openended questions designed to elicit teachers' perceptions of the strengths and weaknesses of the PD, the quality of the PD relative to other PD experiences, and teachers' intent to implement what they learned.

Data from Likert-scale items on each participant's pre-, post-, and year-end PINCK Survey were analyzed using descriptive and inferential statistics. School team means were calculated and univariate analysis of covariance analysis of covariance (ANCOVA) was used to compare treatment and control school teams' year-end confidence in integrating PBL, inquiry, and NOS into instruction, when outcome scores were controlled for preassessment confidence. ANCOVA also explored differences between treatment and control teacher teams' year-end understandings of PBL, inquiry, and NOS when controlling for preunderstanding. 
TABLE 3 Coding understandings and implementation of problem-based learning and inquiry

\begin{tabular}{|c|c|c|c|}
\hline & Nonaligned & Partially aligned & Fully aligned \\
\hline $\begin{array}{l}\text { Problem- } \\
\text { based } \\
\text { learning } \\
\text { (PBL) }\end{array}$ & $\begin{array}{l}\text { Responses lack crucial } \\
\text { elements of the PD definition. } \\
\text { Definitions and examples align } \\
\text { better with hands-on science } \\
\text { or inquiry. Response may } \\
\text { define hands-on instruction or } \\
\text { inquiry without } \\
\text { acknowledging the following: } \\
\text { role of authentic context, the } \\
\text { open-ended nature of the } \\
\text { task, meaningful problem, and } \\
\text { duration or response explicitly } \\
\text { indicates participant doesn't } \\
\text { know. }\end{array}$ & $\begin{array}{l}\text { Definitions and examples suggest } \\
\text { a partial understanding of PBL } \\
\text { and its key features. Response } \\
\text { indicates a role for inquiry and } \\
\text { authentic (real-world) context } \\
\text { in PBL and may acknowledge a } \\
\text { subset of the following: } \\
\text { meaningful problem for students } \\
\text { to solve, open-ended nature of } \\
\text { the task or the extended } \\
\text { duration of such lessons. } \\
\text { Examples may overemphasize } \\
\text { the teacher as the information } \\
\text { provider. }\end{array}$ & $\begin{array}{l}\text { Definitions/examples } \\
\text { accurately reflect the PD } \\
\text { definition: A form of inquiry in } \\
\text { which students solve a } \\
\text { meaningful problem with } \\
\text { multiple solutions over time, as } \\
\text { a scientist would in a real-world } \\
\text { context. The problem and } \\
\text { context must be meaningful to } \\
\text { students. Essential } \\
\text { components that may be } \\
\text { included in response: theme, } \\
\text { problem, student roles, } \\
\text { scenario, resources, } \\
\text { culminating project/ } \\
\text { assessment, safety. }\end{array}$ \\
\hline Inquiry & $\begin{array}{l}\text { Responses lack crucial } \\
\text { elements of the PD definition } \\
\text { (i.e., indicates only a role for } \\
\text { questioning or hands-on, no } \\
\text { indication of analysis of data } \\
\text { on the part of students) or } \\
\text { response is expanded to } \\
\text { include PBL or response } \\
\text { explicitly indicates participant } \\
\text { doesn't know. }\end{array}$ & $\begin{array}{l}\text { Definitions and examples suggest } \\
\text { a partial understanding of } \\
\text { inquiry and its key features. It } \\
\text { may indicate that students do } \\
\text { only one of the following: (a) } \\
\text { analyze data, (b) solve problems, } \\
\text { (c) answer questions through } \\
\text { investigation. Participants may } \\
\text { cite students conducting } \\
\text { "investigations" without } \\
\text { elaboration. Response may } \\
\text { indicate inquiry must be hands- } \\
\text { on or overemphasizes "the" } \\
\text { scientific method and } \\
\text { experimentation. Examples may } \\
\text { overemphasize the teacher as } \\
\text { the information provider. }\end{array}$ & $\begin{array}{l}\text { Definitions/examples } \\
\text { accurately reflect the PD } \\
\text { definition: asking questions, } \\
\text { collecting and analyzing data, } \\
\text { using evidence to solve } \\
\text { problems. Key components } \\
\text { that may be included in } \\
\text { response: learners engage in } \\
\text { scientifically oriented } \\
\text { questions, gives priority to } \\
\text { evidence, formulates } \\
\text { explanations from evidence, } \\
\text { connects explanation to } \\
\text { scientific knowledge, } \\
\text { communicates and justifies } \\
\text { explanations. }\end{array}$ \\
\hline
\end{tabular}

Note: Evidence of italicized components must be present for a response to be coded at the level. Coding of both the definition and application to the classroom (teacher and student actions) provided by participants should be weighed in coming up with a classification for the response on a given dimension. If there are discrepancies between coding of the definition and explanation, the application component should carry more weight. For example, if the participant gives the PD definition verbatim (fully aligned), but their description of classroom application does not reflect aligned implementation, coding should err toward the response of the description of how this approach is enacted in the classroom. Nonaligned perspectives of the NOS (e.g., "proving," overemphasis on "the" scientific method) in responses about PBL and inquiry should be taken into account when coding participants' NOS understandings.

Abbreviations: NOS, nature of science; PBL, problem-based learning; PD, professional development.

\subsection{2 | Interviews}

Following analysis of the pre- and post-PINCK Survey, approximately $20 \%$ of treatment teachers $(n=31)$ across cohorts and sites were purposefully selected for a follow-up semi-structured interview about their experience. These participants were selected because their preintervention and postintervention survey responses provided representation across three categories (i.e., little, moderate, or great changes) in their understanding of inquiry, PBL, and NOS. Interview questions elicited teachers' perspectives on the most and least valuable aspects of the PD, components of the PD they planned to implement, and their suggestions for improvement. These interviews also 
TABLE 4 Coding NOS understandings and instruction

\begin{tabular}{|c|c|c|}
\hline Nonaligned & Partially aligned & Fully aligned \\
\hline $\begin{array}{l}\text { Response includes statements that } \\
\text { reflect absolute views of science. }\end{array}$ & $\begin{array}{l}\text { Response indicates a partial } \\
\text { understanding of the tentative } \\
\text { and revisionary nature of } \\
\text { science. }\end{array}$ & $\begin{array}{l}\text { Response reflects tentative and } \\
\text { revisionary views of science } \\
\text { consistent with the aspects of NOS } \\
\text { taught in PD. }\end{array}$ \\
\hline or & $\begin{array}{l}\text { Response lists key elements of } \\
\text { NOS taught in PD without any } \\
\text { elaboration. }\end{array}$ & $\begin{array}{l}\text { Response must include the following } \\
\text { key elements of the PD description } \\
\text { of NOS: }\end{array}$ \\
\hline $\begin{array}{l}\text { Response does not address any key } \\
\text { elements of the PD description of } \\
\text { NOS }\end{array}$ & $\underline{\text { or }}$ & $\begin{array}{l}\text { Scientific knowledge is tentative and } \\
\text { revisionary. }\end{array}$ \\
\hline or & $\begin{array}{l}\text { Response does not include all of } \\
\text { the key elements of the PD } \\
\text { description of NOS. }\end{array}$ & $\begin{array}{l}\text { Scientific knowledge is empirically- } \\
\text { based. }\end{array}$ \\
\hline \multirow[t]{2}{*}{$\begin{array}{l}\text { Response indicates the participant } \\
\text { does not know. }\end{array}$} & or & $\begin{array}{l}\text { Social/cultural factors play a role in } \\
\text { the development of scientific } \\
\text { knowledge. }\end{array}$ \\
\hline & $\begin{array}{l}\text { Response includes all key aspects } \\
\text { but includes misconceptions } \\
\text { about these aspects. }\end{array}$ & \\
\hline Implicit & & Explicit \\
\hline $\begin{array}{l}\text { Responses indicate that nature of } \\
\text { science is taught effectively through } \\
\text { implicit approaches and instruction. } \\
\text { Responses indicate students will } \\
\text { develop accurate conceptions of the } \\
\text { nature of science as a byproduct of } \\
\text { learning historical episodes of } \\
\text { scientific knowledge and/or } \\
\text { participating in authentic scientific } \\
\text { investigations. }\end{array}$ & & $\begin{array}{l}\text { Responses indicate that nature of } \\
\text { science is taught effectively through } \\
\text { explicit instruction. Responses } \\
\text { indicate students will develop } \\
\text { accurate conceptions of the nature } \\
\text { of science through instruction that } \\
\text { intentionally draws attention to } \\
\text { targeted aspects of the nature of } \\
\text { science through such methods as } \\
\text { discussion, reflection, and } \\
\text { questioning. }\end{array}$ \\
\hline
\end{tabular}

Note: This two-part component of the rubric assesses the extent to which responses express tentative and revisionary view of NOS and the extent to which responses indicate that these aspects of NOS must be explicitly addressed in science teaching. Responses are coded based on the degree of alignment between responses and the PD description of understandings of NOS in Figure 1. With regard to teaching NOS, responses are coded as implicit, if the response indicates that students will learn about NOS from implicit approaches or explicit if the response indicates explicit instruction is required to effectively teach NOS.

Abbreviations: NOS, nature of science; PD, professional development.

served to triangulate with survey responses in that we reviewed interview responses for language that reflected consistency in understanding and confidence.

An inductive approach, as described by Bogdan and Biklen (1992), was used to analyze the open-ended survey responses and follow-up interviews to characterize participants' perceptions of how the PD facilitated changes in their understandings, confidence, and practices. After an initial holistic reading of the data set by two members of the research team, codes were initially developed from the conceptual framework (e.g., inquiry, NOS, PBL, collective participation, active learning, coherence, coaching, understanding, confidence, practice) and the holistic reading (e.g., PD logistics, intentions to implement). These same members of the research team then applied the coding scheme to the data and patterns in relationships between codes were identified and discussed. For example, many teachers identified the importance of having the opportunity to teach students during the camp weeks of the 


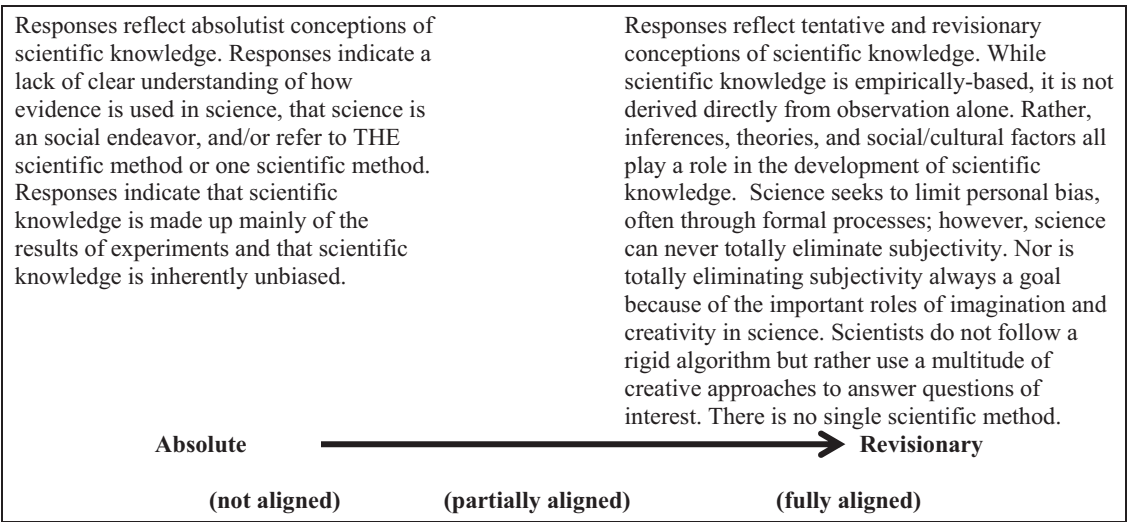

FIGURE 1 Description of PD understandings of NOS. NOS, nature of science; PD, professional development

PD. These instances were coded as "active learning." The patterns that emerged from the coding process were then discussed among the entire research team and refined to ensure they captured the essence of the data set. Once all members of the team agreed upon the patterns that emerged, the analysis was to be considered complete.

\subsection{3 | Classroom observations}

Each participant's classroom instruction was videotaped four times throughout the academic year at regular intervals (two fall and two spring). Each interval was 3-week long to provide some flexibility in terms of the school, teacher, and observer schedule. Observers visited each teacher's classroom once during each observation period to videotape their science instruction. One potential concern of this approach was that for teachers in the treatment condition, these observations were recorded by their coach. However, the coach's role for the videotaped observations was simply to set up a video camera in the back of the room and then send the recorded videotapes back to the research team for analysis. The observed lessons were not directly influenced by the coach before the lesson being implemented/observed (no coinstruction, coplanning, prompts, etc.). All teachers had some knowledge ahead of time of when they would be observed, which had the potential to bias what they did during observations. To mitigate this, the research team also collected contextual information regarding the observed lesson per a validated observation protocol. This information was completed by the teachers and included objectives, what lessons occurred before the observation, and what teachers anticipated teaching in lessons that followed the videotaped lesson in an attempt to capture what the teacher's instruction was like over time. Further, teachers and coaches in the treatment condition knew only that data were being collected, but not how the data would be analyzed.

Videotapes were analyzed using a slightly modified and validated version of the Collaboratives for Excellence in Teacher Preparation and Classroom Observation Protocol (CETP-COP; Appeldoorn, 2004) by the research team.

LI inquiry lab/activity: Students answer a research question through data analysis. (May be handson or not, may be with a pre-existing data set.)

NOS explicit nature of science instruction: Teacher intentionally draws students' attention to targeted aspects of the nature of science through discussion, reflection, and specific questioning. $\boldsymbol{P B L}$ problem-based learning activity: Students solve a problem with multiple solutions over time like a scientist in a real-world context. (An entire observation may be coded PBL if the activity observed is part of a broader PBL unit.)

FIGURE 2 Coding scheme used to determine the presence or absence of PBL, inquiry, and NOS in observations. NOS, nature of science; PBL, problem-based learning 
Neither observers nor coaches participated in any analysis. The CETP-COP instrument assesses four dimensions related to teachers' science instruction at 5-min intervals across the entire lesson duration (i.e., instructional approaches, classroom engagement, cognitive activity, and quality of lesson). The focus of classroom observations in the present study was on participants' classroom enactment of PBL, NOS, and inquiry; however, the original CETP-COP does not specifically target these constructs. Therefore, the researchers added items to the observation protocol to record whether participating teachers enacted such instruction. This slightly modified version of the CETP-COP was validated for content validity through two rounds of feedback and revision from a panel of three experts with backgrounds in science education and research evaluation.

For instruction codes, which are reported here, the presence (1) or absence (0) of inquiry (students answer a research question through data analysis; may be hands-on or not, may be with a preexisting data set), explicit NOS instruction (teacher intentionally draws students' attention to targeted aspects of the NOS through discussion, reflection, and specific questioning), and whether the observed lesson was part of a PBL unit (students solve a problem with multiple solutions over time like a scientist in a real-world context. An entire observation may be coded PBL if the activity observed is part of a broader PBL unit) were coded for each teacher. Since each of the three variables was coded dichotomously for each teacher on the team (observed $=1$ ) or (not observed $=0$ ), teacher team means were calculated and ranged from 0 (no teachers on the team used the instructional approach) to 1 (all teachers on the team used the approach) for each timepoint and across all timepoints. Before coding, raters attended an 8-hr session in which the learned to use code observations using the CETP-COP instrument. Following training, the raters analyzed five video-recorded lessons. Generalizability theory was employed to estimate reliability because we had multiple raters (Shavelson \& Webb, 1991). Generalizability theory provides a comprehensive framework for estimating reliability that takes into account several potential sources of error. The results of this analysis indicated that the generalizability coefficient was $\rho=0.71$ for two raters. The average interrater agreement reported by CETP-COP developers was 71\% (Appeldoorn, 2004). Considering all sources of error, a generalizability coefficient of 0.7 indicates high reliability, especially for an open-ended instrument. Approximately 6 months after initial training, all raters coded another video and discussed their coding, which served as a drift check. This helped maintain consistency across raters in applying codes over time. Independent $t$ tests were then used to compare differences in treatment and control teacher teams' incorporation of PBL, NOS, and inquiry into instruction each of the four timepoints and overall.

\subsection{4 | Relationships between condition, confidence, understanding, and practice}

Three multiple regressions were used to ascertain how teacher team understandings, confidence, practice, and PD participation were related for PBL, inquiry, and NOS, respectively. Predictors included team condition (treatment or control), postsummer institute understanding, and postsummer institute confidence. The outcome variable was the overall implementation by the team. Preliminary analyses were conducted to ensure no violation of the assumptions of normality, linearity, mutlicollinearity, and homoscedasticity. A Bonferroni adjusted $\alpha$ level was set at $.0167(.05 / 3)$ to account for multiple comparisons.

\section{6 | RESULTS}

Overall, treatment teacher teams' understandings and confidence in implementing reform-based practices were significantly greater than those of control teacher teams' after participation in the PD. In addition, treatment teacher teams implemented PBL, inquiry, and explicit NOS instruction significantly more than their peers in the control group, with the exception of inquiry during the third observation period. 


\section{1 | Understandings of reform-based instructional strategies}

Treatment teams' understanding of PBL, inquiry, and NOS improved following the summer institute (all pre to post $p s<.001$; Table 5) and were retained at the end of the year (all post to year-end $p s>.05$ ). Treatment and control teacher teams' year-end understandings of PBL, inquiry, and NOS understandings were compared via univariate analysis of variance (Table 5 ). Results were statistically significant for all indicators ( $p s<.001$ ) favoring the treatment group outcomes. Treatment group means approached the middle of the scale (partially aligned) for each construct while the control group means were between not aligned and partially aligned for all constructs. The greatest differences favored treatment teams' understandings of NOS. Effect sizes were large for all constructs (J. Cohen, 1988) ranging from partial $\eta^{2}=0.173$ for NOS instruction to partial $\eta^{2}=0.460$ for NOS understandings.

Before the study, most teachers provided responses that did not reflect the aligned understandings of PBL, inquiry, and NOS. Following the PD, treatment teachers made statements that reflected more aligned understandings of these constructs than their counterparts in the control group (Table 6). For example, treatment teachers' responses about inquiry were more often partially or fully aligned and often reflected more broad understandings of the types of investigations scientists employ when engaging in inquiry whereas control teachers' partially aligned responses about inquiry instruction often emphasized the scientific method and experimentation. Treatment teachers were more likely to include inquiry and real-world problems as components PBL. By contrast, many control teachers continued to conflate inquiry with PBL. Finally, treatment teachers were more likely to provide partially aligned or fully responses about NOS instruction; almost all control teachers retained not aligned understandings of NOS. In fact, many control teachers explicitly stated they did not know what NOS is or what teachers or students do during a NOS lesson. Most treatment and control teachers retained the conception that students could learn NOS implicitly.

Participants attributed their improved understandings to the PD. For example, one participant described the process through which the facilitators introduced the concepts: "I've always kind of put inquiry and handson as being synonyms. And now I can see that the inquiry is where the students are actually asking the questions themselves and using evidence" (E3-T310, Interview). This participant indicated that following the PD she had a better understanding of the constructs as a result of the structure of how the concepts were introduced during the PD. Another participant summarized, "I like the way we were learners first, then planned and implemented a PBL to practice, and then had time to work our own" (E3-T310, Post-PINCK Survey). Others echoed this sentiment, "It was easy to learn them because I was doing them. I think if they just taught us what it was, it wouldn't have been as concrete as participating in it and planning it for campers." (E3-T370, Interview). This teacher continued:

TABLE 5 School team understanding of key constructs

\begin{tabular}{|c|c|c|c|c|c|c|c|}
\hline & \multicolumn{2}{|c|}{ Pre-PD, M (SD) } & \multirow{2}{*}{$\begin{array}{l}\text { Post-PD, M (SD) } \\
\text { Treatment }\end{array}$} & \multicolumn{2}{|c|}{ Year-end, $M(S D)$} & \multirow[b]{2}{*}{$p$} & \multirow[b]{2}{*}{ partial $\eta^{2}$} \\
\hline & Treatment & Control & & Treatment & Control & & \\
\hline PBL & $1.06(0.18)$ & $1.13(0.24)$ & $1.83(0.64)$ & $1.63(0.66)$ & $1.05(0.15)$ & $<0.001$ & 0.261 \\
\hline Inquiry & $1.43(0.37)$ & $1.61(0.47)$ & $1.95(0.58)$ & $2.10(0.54)$ & $1.60(0.54)$ & $<0.001$ & 0.207 \\
\hline NOS understanding & $1.08(0.17)$ & $1.19(0.30)$ & $1.98(0.54)$ & $1.91(0.55)$ & $1.10(0.22)$ & $<0.001$ & 0.460 \\
\hline NOS instruction & $1.00(0.00)$ & $1.00(0.00)$ & $1.46(0.36)$ & $1.35(0.37)$ & $1.06(0.20)$ & $<0.001$ & 0.173 \\
\hline
\end{tabular}

Note: Treatment $n=54$, control $n=40$, means adjusted for school team baseline premeasure. For PBL, inquiry, and NOS understandings, scale ranges from $1=$ not aligned to $3=$ fully aligned. For NOS instruction, scale ranges from $1=$ implicit to 2 = explicit.

Abbreviations: NOS, nature of science; PBL, problem-based learning; PD, professional development; SD, standard deviation. 
TABLE 6 Representative survey responses of treatment and control teachers' pre and year-end understandings of PBL, inquiry, and NOS

$\begin{array}{ll}\text { Construct } & \text { Year-end treatment }^{\mathrm{a}} \\ \text { PBL } & \text { Teachers present the problem, allow students to } \\ & \text { research answers to the problem, and students } \\ & \text { then perform hands-on, inquiry-based activities } \\ & \text { to find answers to the real-life problem. } \\ & \text { (partially aligned, E2-T240) }\end{array}$

\section{Year-end control ${ }^{\mathrm{a}}$}

... an instructional approach in which a problem is posed to students and the students complete a project/assignment that shows a solution. For example, the question, "Which container will $100 \mathrm{ml}$ of water evaporate the fastest in?" Students would need to research evaporation and design an experiment to answer the question. (not aligned, E2CT226)

Students are presented with a problem within a group. They develop possible theories or hypothesis to explain the problem. They use hands-on activities, research and other learning activities working together in groups to seek solutions to real problems through the process of inquiry. (partially aligned, E2-T204)

Inquiry

It can be defined as the scientific process of active exploration by which we use critical, logical and creative-thinking skills to raise and engage in questions of personal interests. Students learn by observing or engaging in an event, devising questions based on their observations, developing hypotheses, formulating strategies for testing their theories, performing the tests, analyzing and drawing conclusions from test results, and communicating their findings to others. fully aligned, E3-T339)

Inquiry occurs when students ask questions about what occurs around them in the real world. Students collect evidence and data related to the questions being asked/answered. Students use reasoning to move closer to a solution. In the true inquiry, they realize that often there is not a distinct correct answer, which is a different mindset from the kind they are used to in school. Students find out that inquiry often leads to more questions rather than answers alone. (fully aligned, E3-T334)

NOS understandings
The "Nature of Science" consists of those seldomtaught but very important features of working science. This includes its realm and limits, its levels of uncertainty, its biases, its social aspects, and the reasons for its reliability. The Nature of Science helps limit the many misuses, misrepresentations, and abuses of science. (partially aligned, E3-T303)

The Nature of Science is an important part of science in the real world that allows us to make sense of the world around us. It involves
A question is stated and the students work to find an answer. (not aligned, E2CT221)

Science inquiry consists of conducting science experiments in the classroom to understand physics and the world around us. Students will be asking the questions and taking the steps needed to understand the given problem of an experiment. (partially aligned, E3СT326)

Scientific inquiry is an ongoing process where we are continuously learning about the world around us. It is the Scientific Method; we propose a hypothesis then we test it and gather evidence to provide an explanation for why things occur as they do. (partially aligned, E3CT345)

The nature of science is inquiry. (not aligned, E2CT225)

Science is an attempt to explain natural or unnatural phenomena in the world or universe. (not aligned, E2CT202) 
TABLE 6 (Continued)

\begin{tabular}{|c|c|c|}
\hline Construct & Year-end treatment ${ }^{a}$ & Year-end control $^{\mathrm{a}}$ \\
\hline & $\begin{array}{l}\text { understanding and communicating the following } \\
\text { tenets through our scientific inquiries: Scientific } \\
\text { ideas are both durable and subject to change; } \\
\text { we have the confidence that scientific } \\
\text { knowledge is reasonably long-lasting; however, } \\
\text { it may change or be modified as we learn more. } \\
\text { Science demands evidence; we demand } \\
\text { explanations (part of human nature) but these } \\
\text { explanations must be based on evidence that is } \\
\text { testable, and observable. The natural world is } \\
\text { understandable; much of what we do in } \\
\text { scientific learning involves understanding or } \\
\text { answering questions about real-world } \\
\text { phenomena. Science avoids bias, as much as } \\
\text { humanly possible; we are keenly aware of our } \\
\text { ability for bias and seek to work in a realm that } \\
\text { remains objective rather than subjective. } \\
\text { Science is a blend of logic and imagination. } \\
\text { Science is a social activity, as we discuss, debate, } \\
\text { share ideas, and collaborate to find answers to } \\
\text { our questions. (fully aligned, E2-T241) }\end{array}$ & $\begin{array}{l}\text { I really don't know what nature of science } \\
\text { means. Maybe it means research, } \\
\text { investigation, and models? Or perhaps } \\
\text { how science works? (not aligned, } \\
\text { E3CT346) }\end{array}$ \\
\hline NOS instruction & $\begin{array}{l}\text { During a lesson emphasizing the nature of } \\
\text { science, the students are acting like, and } \\
\text { thinking like scientists! (implicit, E2-T251) } \\
\text { For an explicit NOS lesson/activity, you pull in } \\
\text { the tenets which have been introduced ... If you } \\
\text { are emphasizing science demands evidence and } \\
\text { is social and based on observation and } \\
\text { inference. You would stop at points of the lab } \\
\text { and discuss those tenets explicitly when } \\
\text { applicable. (explicit, E2-T263) }\end{array}$ & $\begin{array}{l}\text { teachers: exposing students to science all } \\
\text { around in nature students: learning from } \\
\text { experiences (implicit, E2CT201) } \\
\text { Discussing how the world around us } \\
\text { works and all the ways that the world is } \\
\text { connected (implicit, E3CT334) } \\
\text { I'm not too familiar with this term and } \\
\text { don't exactly know. (implicit, E3СТ325) }\end{array}$ \\
\hline
\end{tabular}

Abbreviations: NOS, nature of science; PBL, problem-based learning.

${ }^{a}$ These exemplars were selected on all year-end survey responses to reflect the most typical participant responses for that construct.

And then we were given an opportunity to assess others who were going through the teaching opportunity, so we got to see it from three different aspects, which really helped give more dimension to the learning process rather than just being in a direct instruction type role. (E3-T370, Interview).

This participant specifically mentioned the opportunity to observe other teachers teaching in the camp setting, and practice teaching in the camp setting as facilitating her understanding of PBL, inquiry, and NOS.

Another participant commented on the collaborative nature and coherent context as beneficial to their learning:

The PD experience provides opportunities for participants to interact or serve as peer resources. What the participants learn in the PD transfers to behaviors that are observable in the classroom. PD in which participants are given the opportunity to learn new classroom practices in the contexts within which those practices will be used is far more effective than more traditional methods of PD. In other words, PD can be as effective in changing teacher behaviors as contextual teaching in the classroom is in improving student behaviors. (E2-T274, Year-end PINCK Survey) 
Participants universally acknowledged the value of the sustained, on-going PD model that emphasized active learning through collective participation situated within a coherent context as contributing to their improved understandings.

\subsection{Confidence in teaching PBL, inquiry, and NOS}

In addition to improving understandings, results indicated participation in the PD also improved participants' confidence in incorporating PBL, inquiry, and explicit NOS instruction (Table 7). Paired sample $t$ tests indicated that for all assessed indicators, treatment teams exhibited a statistically significant change in their confidence implementing PBL, inquiry, and, NOS ( $p s<.05$ ) pre-PD to year-end.

Teacher teams in the treatment group reported significantly greater confidence than their peers in the control group for all constructs; when year-end outcome group means were adjusted for premeasure scores, all $p s<.001$ (Table 8). Effect sizes were large (J. Cohen, 1988) and ranged from partial $\eta^{2}=0.478$ for confidence integrating PBL to partial $\eta^{2}=0.666$ for confidence integrating explicit NOS instruction.

Several participants mentioned how participating in the PD changed their perspective of how to teach science and how this developed their confidence in implementing the key constructs learned in the PD. For example, E3T334 noted,

I now see science instruction as an active practice that doesn't involve a warehouse of facts and knowledge. [The PD] has driven me to be more invested in the act of exploration, and I hope my students adopt that mindset in the coming school years. I now know how to develop a problem-based unit and take the steps necessary to plan it. (E3-T334, Post-PINCK Survey)

Participants repeatedly discussed how specific components of the PD were important in facilitating their confidence in implementing reform-based science instruction into their own practice. For example, one teacher described how many of the effective characteristics of PD (active learning, collective participation, expert coaching) of the PD facilitated her confidence:

I really enjoyed the camp and being able to practice what we were learning about, what we were taught, I think that was crucial to be able to become more comfortable with what we were going to be doing in our classroom this coming year. And I also liked the time we had to plan and plan with other teachers from other areas in order to come up with a cohesive plan. (E3-T337, Interview)

As the above example illustrates, implementing a PBL unit at camp not only provided participants with an opportunity for active learning, but also a chance to get feedback on their teaching. Participants cited the time to reflect and receive feedback as valuable because it increased learning and because time to reflect and material resources are not typically features of other PD or teaching during the academic school year.

TABLE 7 Paired samples $t$ tests for treatment teams' pre-/year-end confidence

\begin{tabular}{|lllll|}
\hline Paired indicator (pre-/year-end) & Pre-PD & Year-end PD & $\boldsymbol{t}$ & $\boldsymbol{p}$ \\
\hline PBL activities & $2.44(0.74)$ & $3.11(0.94)$ & 10.38 & $<0.001$ \\
\hline Inquiry-based activities & $2.59(0.80)$ & $3.38(0.97)$ & 10.03 & $<0.001$ \\
\hline Explicit NOS instruction & $2.15(0.85)$ & $3.20(1.1)$ & 12.07 & $<0.001$
\end{tabular}

Abbreviations: NOS, nature of science; PBL, problem-based learning; PD, professional development. 
TABLE 8 School team confidence in incorporating key constructs

\begin{tabular}{|c|c|c|c|c|}
\hline \multirow[b]{2}{*}{ Construct } & \multicolumn{3}{|c|}{ Year-end group means } & \multirow[b]{2}{*}{ Partial $\eta^{2}$} \\
\hline & Treatment $(n=50)$ & Control $(n=38)$ & $p$ & \\
\hline PBL activities & $3.62(0.68)$ & $2.40(0.81)$ & $<0.001$ & 0.478 \\
\hline Inquiry-based activities & $3.01(0.61)$ & $2.63(0.91)$ & $<0.001$ & 0.494 \\
\hline Explicit NOS instruction & $3.93(0.54)$ & $2.17(0.79)$ & $<0.001$ & 0.666 \\
\hline
\end{tabular}

Note: Likert-scale ranges from $1=$ not confident to $5=$ very confident. Adjusted $=$ Year end (delayed post) means adjusted for baseline premeasure.

Abbreviations: NOS, nature of science; PBL, problem-based learning.

Another participant pointed out the collective participation in the PD facilitated her confidence in implementing what she learned into her own instruction:

I LOVE that we have had the chance to work with another teacher from our school and to build that teamtype relationship. [This PD] is the ONLY experience that has taught me a new technique, let me practice that new technique, let me reflect on my implementation of that new technique and supported me to this extent. I feel as with all of the support and materials and experiences given it is literally IMPOSSIBLE to fail in implementation. (E3-T385, Year-end PINCK Survey)

Like E3-T385, many participants attributed their new confidence to the unique aspects of the PD, namely being able to work with their colleagues and other teachers to plan and implement a PBL unit and having opportunities to practice the teaching strategies they learned during the summer institute during the camp. The coherent, contextualized nature of the PD appeared to facilitate teachers' understandings and confidence in implementing PBL, NOS, and inquiry.

\section{3 | Classroom practice}

Participants overwhelmingly indicated they intended to implement what they learned ( $M=4.92$ on 5-point Likert scale, $S D=0.30$; post-PD PINCK Survey). Participants discussed how they perceived they could translate what they learned during the summer institute into their own classroom instruction. One teacher explained, "Even during units that are not my PBL that I designed [during the summer], I will be incorporating the same guiding principles and ideas throughout the entire year." (E2-T239, Post-PINCK Survey). Another noted, "I have participated in other science PD but it was not nearly as immediately applicable to my classroom. I can see how what I learned will impact my teaching of not just science, but all subjects" (E3-T318, Post-PINCK Survey).

Analysis of classroom observations with the modified CETP-COP instrument provided evidence of the extent to which participants' actually incorporated PBL, inquiry, and NOS into instruction. Significantly more treatment teacher teams incorporated PBL and NOS than control teacher teams across all observation windows (Table 9). Integration of inquiry was also statistically different, favoring integration by treatment teacher teams for inquiry during the first, second, and final observation windows.

Classroom observation data were used to qualitatively understand the types of science content taught within PBL units and how teachers incorporated inquiry and explicit NOS instruction within these units. Science content embedded within PBL units included ecosystems, sound, energy transfer, human impact on the environment, and weather. Classroom vignettes (Supporting Information Materials Supplement B), derived from classroom observation data exemplify how teachers incorporated inquiry and NOS into PBL units following participation in the PD. For example, in Vignette 1, which took place in a 4th-grade class, the teacher explicitly linked the NOS 
tenets she wanted to emphasize specific activities in which students engaged throughout the PBL unit. In addition, she incorporated opportunities for students to conduct experiments via online simulations to develop the knowledge necessary to answer the overarching question that served as the unit scenario.

Similarly, the learning objectives for a 5th-grade science PBL unit were to understand the characteristics and interactions of moving objects by investigating and designing a method to speed up or slow down the rate a car travels over different surfaces (E3-T368, Observation 4 Context). This teacher also incorporated opportunities for inquiry through data collection and analysis into the unit. She pointed out to students that they were acting like scientists because they were working together in groups, one of the few NOS ideas teachers were observed teaching explicitly during classroom instruction. However, classroom observation contextual information also indicated the teacher perceived the unit as teaching students the NOS ideas that (a) science is a blend of logic and imagination and that students had to use both during their investigation as well as that (b) scientific knowledge is the project of both observation and inference in that students had to observe the effect of the raceway they created on their cars and then infer how these results would relate to the movement of real cars. There is no evidence; however, the teacher explicitly linked these NOS ideas to what students did during the observed lesson (Supporting Information Materials Supplement B-Classroom Vignette 2).

Many participants' perceived the coaching component as a valuable aspect of the PD that supported their confidence in implementing what they learned during the summer into instruction. For example, participant E3T348 described her interactions with her coach:

From her very first visit to our classroom, [my coach] became a part of our community. She was always extremely helpful and was very flexible. She brought a wealth of knowledge and experience to this position, and she offered ideas in a very professional way. She was often very affirming, with both verbal and nonverbal ways. (E3-T348, Year-end PINCK Survey)

Another echoed the support provided by her coach:

She even came to our school before school started. She helped us plan our lessons for science at times and offered us suggestions on how to keep our students engaged. When she wasn't at our school, she was busy helping us by sending us great resources to use for each unit we taught. (E3-T332, Year-end PINCK Survey)

As evidenced by the above comments, participants' perceived coaches as supporting the transfer of what they learned during the summer institute into effective implementation in their own classroom.

\subsection{Relationships between confidence, understandings, and practice}

Multiple regression was used to determine if understanding, confidence, and condition significantly predicted the implementation of PBL, inquiry, and NOS. For PBL implementation, the results of the regression indicated that the model containing condition, postsummer institute PBL confidence, and postsummer institute PBL understanding explained $51 \%$ of the variance $\left(R^{2}=.51 ; F(3,88)=32.9 ; p<.001\right)$. In the model, the only condition was statistically significant $(\beta=.781 ; p<.001)$. Condition uniquely explained $41 \%$ of the variance in PBL implementation. For inquiry implementation, regression results indicated that the model containing condition, postsummer institute inquiry confidence, and postsummer institute inquiry understanding was not significant $\left(R^{2}=.067, F(3,88)=3.18\right.$; $p=.028$ ). The overall model explained $6.7 \%$ of the variance in inquiry implementation. In the model, condition explained $9 \%$ of the variance in inquiry implementation $(\beta=.31 ; p=.004)$. For NOS implementation, the results of the regression indicated that the model containing condition, postsummer institute NOS confidence, and postsummer institute NOS understanding explained $40 \%$ of the variance $\left(R^{2}=.40 ; F(3,87)=16.4 ; p<.001\right)$. In the 

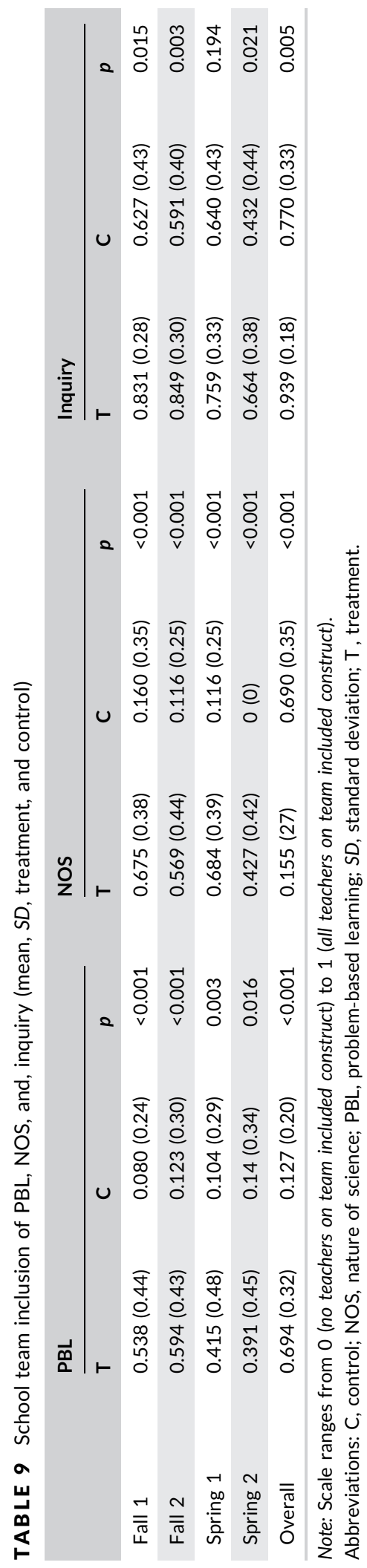
model, the only condition was statistically significant $(\beta=.67 ; p<.001)$. Condition explained $16 \%$ of the variance in NOS implementation. Neither postsummer institute understanding nor confidence significantly predicted classroom implementation in any model.

\section{7 | DISCUSSION}

This RCT explored the effectiveness of the PD in improving elementary science teachers' knowledge of and confidence in implementing PBL, inquiry, and NOS into their classroom instruction. The results of this investigation make several important contributions to the literature. First, the RCT research design allowed us to measure statistically significant positive changes in treatment teachers' understandings, confidence, and practices related to PBL, inquiry, and NOS and attribute these to the PD. Second, teachers converged on several components of the PD they perceived as promoting these changes, which were aligned with the components of effective PD cited elsewhere in the literature as important in supporting teacher change. Each of these contributions is described below.

\section{1 | Changes in understanding, confidence, and instructional practice}

\subsection{1 | Understanding}

Participants made significant gains in their understanding of NOS, inquiry, and PBL instruction following their participation in the PD and their understandings were significantly greater than those of control group teachers. Treatment teachers' knowledge of PBL improved the greatest of the three constructs pre- to postsummer institute and these were retained at the end of the year. Similarly, desired shifts in treatment teachers' understandings of inquiry occurred pre- to year-end and were significantly greater than those of control teacher teams. Research suggests many science teachers do not have accurate conceptions of inquiry (e.g., Johnson, 2006, 2007). For example, some teachers conflate inquiry instruction with hands-on instruction and teaching inquiry with teaching NOS and process skills (Crawford, 2000; NRC, 2000). However, the PD that served as the intervention of the present study appeared to be effective in improving teachers' knowledge of PBL and inquiry.

Participants expressed moderate knowledge about teaching NOS after PD; however, they retained their conception that students would learn about NOS through implicit approaches. This finding is consistent with a large body of literature that teachers do not incorporate explicit NOS instruction (e.g., Bell et al., 1998, 2003; Lederman et al., 2012). Further, participants in the present study learned about NOS instruction through both contextualized and noncontextualized activities such as an investigation in which teachers made observations and inferences about a rock then gathered more evidence and discussed NOS ideas (creativity, empirical evidence, and tentative) that they used during the investigation. Thus, the findings of the present study support Clough's (2006) assertion, that the implementation of explicit NOS instruction should occur along a continuum from noncontextualized to highly contextualized. They also contribute to the ongoing debate concerned with the most effective context to facilitate teachers' capacity to learn and transfer their NOS knowledge to their own classroom instruction (e.g., Bell et al., 2016; Bell, Matkins, \& Gansneder, 2011; Herman, Clough, \& Olson, 2013).

While many studies espouse the success of PD programs that specifically target teachers' inquiry (e.g., Kanter \& Konstantopoulos, 2010; Lotter et al., 2007) or NOS understandings (e.g., Akerson \& Hanuscin, 2007; Akerson, Cullen, \& Hanson, 2009), most of these investigations use a quasi-experimental (e.g., use a pre-/postintervention) design or are qualitative in nature. This study supports the findings of these previous investigations through a mixed-methods RCT. Further, it extends these studies through an exploration of not only inquiry and NOS, but also teachers' understandings of PBL following a PD that embedded inquiry and NOS within a PBL context. 


\subsection{2 | Confidence}

Participants' confidence in targeted reform-based practices increased significantly pre- to year-end and their confidence was greater than those teachers in the control group. Similar findings exist for other investigations of PD to support inquiry (e.g., Brand \& Moore, 2011; Duran, Ballone-Duran, Haney, \& Beltyukova, 2009; Lakshmanan et al., 2011; Sandholtz \& Ringstaff, 2014). However, the majority of these studies employ a qualitative or quasiexperimental design and focus on preservice teachers or secondary teachers. Thus, the results of the present investigation substantiate these findings among elementary teachers. Notably, the present investigation also extends the body of literature on PD to support the development of science teachers' confidence by exploring their confidence in developing and implementing NOS and PBL instruction.

\subsection{3 | Instructional practices}

The present study explored participants' reform-based practices during four observations of windows spread throughout the academic year. While approximately $50 \%$ of participants were observed integrating the targeted reform-based practices, this is likely an underestimate, as some may have integrated these pedagogical approaches outside the observation windows. Despite this potential limitation of the study, overall, results indicated teacher teams who participated in the PD integrated targeted reform-based practices (i.e., NOS, inquiry, and PBL) significantly more frequently than their control group counterparts across all observation windows except inquiry during the first spring observation window. While most studies of the effectiveness of PD employ teacher selfreport data rather than classroom observations of teachers' instruction (Roth et al., 2011), the present study extends these by using a validated observation protocol to record instances of reform-based instruction.

Previous research suggests effective NOS instruction does not come easily for most teachers (e.g., Akerson \& Abd-El-Khalick, 2003; Bell et al., 1998; Lederman, 2007; Lederman et al., 2012). In the present investigation, treatment teachers incorporated significantly more explicit NOS into their instruction than control teachers across all four observation points. In fact, for all time periods except the late spring window, the mean number of teachers on a treatment team who implemented NOS instruction was more than half of the teachers on the team. This suggests that not only were teachers integrating explicit NOS into instruction to a substantive extent, but they were doing it more consistently across the year than some might expect. Often, NOS is taught near the beginning of the year during instruction on scientific methodology. Results indicated treatment teacher teams' implemented inquiry to a greater extent than control teacher teams across all observation windows except the first spring window. These findings extend previous studies, most of which do not look at snapshots of teachers' instruction over the entire academic year, but often observe teachers during an instructional unit or abbreviated timeframe.

Classroom observations revealed teachers incorporated PBL more frequently in the fall semester, in closer proximity to when they learned it, than in the spring, whereas participants tended to incorporate NOS and inquiry more consistently throughout the year. The modest improvements in PBL instruction are not unexpected for several reasons. Inquiry instruction was more familiar to participants and is a more straightforward pedagogical approach to implement than developing and implementing and entire PBL unit. Designing and implementing PBL into instruction is a complex process. It relies heavily upon students' exploration and synthesis of multiple science concepts within a coherent instructional unit to solve a problem with multiple possible solutions (Center of Excellence in Leadership of Learning, 2009; Sterling, 2007; Thomas, 2000). Thus, the process of designing and implementing PBL may be especially difficult for elementary teachers who may not be science content experts as previous research suggests some degree of content knowledge expertise may be necessary but insufficient to facilitate teachers' effective science instruction (Abell, 2007).

Although significantly less than those teachers in the control group, many of the treatment participants' still expressed the nonaligned understanding that effective NOS instruction could be implicit following the PD. Thus, a 
disconnect between teachers' understanding of explicit NOS instruction and their explicit NOS instructional practices appeared to exist. This finding supports previous research that teachers' practices may not reflect their understandings about NOS (e.g., Bell, Lederman, \& Abd-El-Khalick, 2000; Lederman, 2007; Schwartz \& Lederman, 2002). However, those studies focused on preservice and in-service secondary teachers and found that while teachers' accurate conceptions of NOS were present, their instructional practices did not include extensive explicit NOS instruction. Thus, our findings for elementary teachers warrant further exploration.

Our multiple regression results indicated that participation in the PD rather than confidence and understanding contributed to teachers' classroom implementation of PBL and NOS. This is an important finding in that it indicates that PD may mediate the relationship between confidence and understandings on implementation, and explain discrepancies in the results of previous investigations. Some scholars argue there is a clear connection between understandings and practice (e.g., Brand \& Moore, 2011; Goodhew \& Robertson, 2017; Lakshmanan et al., 2011), while others have found this relationship to be complex and that understandings do not directly transfer into classroom practice (Beyer \& Davis, 2008; Lederman, 1999). Further, a number of studies indicate elementary teachers' confidence influences their reform-based inquiry and NOS instructional practices (e.g., Lakshmanan et al., 2011; Ramey-Gassert et al., 1996; Sandholtz \& Ringstaff, 2014). The relationship between understanding and practice is well-documented for inquiry and indicates that teachers' understandings and confidence positively influence their practices (e.g., Brand \& Moore, 2011; Lakshmanan et al., 2011), yet the relationship between teachers' understandings of PBL and their classroom implementation of PBL has not been well-studied. Given the results of the present study, the complexity of these pathways as well as the potential role PD plays in mediating classroom implementation with regard to understandings and confidence warrants further investigation.

\section{2 | Efficacy of embedded components of effective PD}

Overall, the PD appeared to contribute to the changes in participants' understandings, confidence, and practices. For many participants, active learning opportunities incorporating inquiry and NOS instruction, opportunities to practice PBL, NOS, and inquiry instruction in the context of camp before implementing these constructs in their own classrooms facilitated transfer to their own instruction. Participants also cited collaborating with peers when designing instruction and receiving feedback from coaches and instructors as encouraging the integration of reform-based practices into their instruction. The incorporation of these active learning opportunities and the requirement of collective participation appeared to promote participants' transfer of what they learned in the PD into their own reform-based instruction.

The summer institute constituted only one component of the PD experience. Participants were provided support throughout the academic year through follow-up sessions and coaching, which provided sustained, ongoing, coherent PD with expert coaching. Follow-up and coaching sessions were designed to reinforce what participants initially experienced during the summer institute and promote transfer to the classroom environment. Participants perceived these components to be important in supporting their improved practices. These longitudinal and contextualized features of the PD are often cited as essential features of effective PD (e.g., Desimone, 2009; Johnson et al., 2007; Supovitz \& Turner, 2000), yet are often costly to implement.

Results of the present study support the inclusion of these features into PD for elementary science teachers as participants' retained their understandings of PBL, inquiry, and NOS instruction across the year. In addition, participants integrated these constructs relatively consistently across the year, with slightly higher integration in the fall. Therefore, the results of the present study provide further support for the importance of taking a situated approach to the design of PD for elementary teachers (e.g., Voogt et al., 2015). It is possible that the components of effective PD (e.g., longitudinal, contextualized, opportunities for active learning, collective participation, expert coaching) embedded within the PD that served as the intervention facilitated participants in overcoming the barriers elementary teachers face when implementing reform-based practices in their instruction. Ascertaining the 
extent to which each of the components contributed to participants' understanding, confidence, and practice is an area for future research.

\section{3 | Future research}

This investigation addressed the effect of a PD program on teachers' knowledge and confidence as well as how they translated that understanding into their classroom practices through an RCT. This investigation also provides a number of directions for future research. First, research suggests a teacher's disciplinary content knowledge may impact their confidence and practice (e.g., Abell \& Roth, 1992; Akerson, 2005; Capps \& Crawford, 2013; Lee, 2003). However, this study did not focus on this aspect of the participants' background. Given the intensity of data collection in the present investigation and the desire not to overburden teachers, the present study did not include a specific assessment of teacher content knowledge before or after the PD. Future studies may seek to delineate specific connections to teachers' content knowledge and outcomes. Second, the definitions of PBL, inquiry, and NOS used during the PD were intended to capture the main ideas of the construct but were not comprehensive. This decision to include only the most critical aspects was made because the PD included a lot of material in a limited amount of time. Future studies might choose to investigate in more detail the impact of PD on the individual constructs on knowledge, confidence, practice, and student achievement; however, doing so may mitigate any advantage of the synergistic approach employed in the PD in this investigation. Importantly, previous research suggests that reform-based practices including PBL, inquiry, and NOS instruction have the potential to improve student achievement (e.g., Bransford, Brown, \& Cocking, 2000; Cleminson, 1990; Peters, 2012; Songer \& Linn, 1991) for all students. Thus, future studies should investigate the impact of the PD on student achievement and the teacher level factors that moderate this relationship.

\section{CONCLUSION}

The reform-based pedagogies presented in the PD aimed to shift science instruction beyond a content-only focus to address the important goal of enhancing students' scientific literacy. Inquiry lessons overlap with many aspects of scientific literacy such as having students evaluate evidence, formulate scientific explanations and engage in scientific discourse, while NOS lessons help students reflect on how these practices connect to scientific epistemology. The incorporation of both inquiry and NOS instruction into PBL units has the potential to make science more contextualized and meaningful to students.

Overall, the positive improvements in teacher understanding, confidence, and practices related to PBL, inquiry, and NOS are heartening given the significant, numerous barriers to reform-based instruction documented in the literature (e.g., Arora et al., 2000; Bauer \& Kenton, 2005; Johnson, 2006, 2007; Lakshmanan et al., 2011; Lederman, 2007; Sandholtz \& Ringstaff, 2014; Supovitz \& Turner, 2000). Teachers specifically attributed opportunities for active learning, practice, collaboration, and receiving feedback from coaches and instructors embedded within the PD as contributing to their improved understandings, confidence, and instruction. It is possible that these components of the PD facilitated teachers' overcoming documented barriers to implement targeted reform-based practices. Thus, in light of the positive results reported here, designers of PD should specifically consider the inclusion of these features into PD to support elementary teachers' reform-based science instruction.

\section{ACKNOWLEDGMENTS}

We thank members of the project research team including Amanda Gonczi, Timothy Konold, Jenay Sharp Leach, Shannon Navy, Kathan Shukla, and Lindsay Wheeler. This research was supported by funding from the U.S. 
Department of Education Investing in Innovation (I3) grant program (grant: \#U396B100039). However, the results presented here do not necessarily represent the policy of the U.S. Department of Education, and should not assume endorsement by the Federal government.

\section{ORCID}

Jennifer L. Maeng (D) http://orcid.org/0000-0003-4955-4023

Brooke A. Whitworth (iD http://orcid.org/0000-0002-3944-291X

\section{REFERENCES}

Abd-El-Khalick, F. S., \& Akerson, V. L. (2004). Learning as conceptual change: Factors mediating the development of preservice elementary teachers' views of NOS. Science Education, 88, 785-810.

Abell, S. (2007). Research on science teacher knowledge. In S. K. Abell \& N. G. Lederman (Eds.), Handbook of research on science education (pp. 81105-81149). Mahwah, NJ: Lawrence Erlbaum Associates.

Abell, S., \& Roth, M. (1992). Constraints to teaching elementary science: A case study of a science enthusiast student teacher. Science Education, 76, 581-595.

Akerson, V. L. (2005). How do elementary teachers compensate for incomplete science content knowledge? Research in Science Education, 35, 245-268.

Akerson, V. L., Cullen, T. A., \& Hanson, D. L. (2009). Fostering a community of practice through a professional development program to improve elementary teachers' view of nature of science and teaching practice. Journal of Research in Science Teaching, 46, 1090-1113. https://doi.org/10.1002/tea.20303

Akerson, V., \& Hanuscin, D. (2007). Teaching nature of science through inquiry: Results of a 3-year professional development program. Journal of Research in Science Teaching, 44, 653-680.

Akerson, V. L., \& Abd-El-Khalick, F. (2003). Teaching elements of NOS: A yearlong case study of a fourth-grade teacher. Journal of Research in Science Teaching, 40, 1025-1049.

Appeldoorn, K. (2004). Developing and validating the Collaboratives for Excellence in Teacher Preparation (CETP) core evaluation classroom observation protocol (COP). (PhD dissertation), University of Minnesota, Minneapolis, MN.

Arora, A., Kean, E., \& Anthony, J. (2000). An interpretive study of a teacher's evolving practice of elementary school science. Journal of Science Teacher Education, 11, 155-172.

Bandura, A. (1986). Social foundations of thought and action: A social cognitive theory. Englewood Cliffs, NJ: Prentice-Hall.

Banilower, E. R., Smith, P. S., Malzahn, K. A., Plumley, C. L., Gordon, E. M., \& Hayes, M. L. (2018). Report of the 2018 NSSME+. Chapel Hill, NC: Horizon Research, Inc.

Bauer, J., \& Kenton, J. (2005). Toward technology integration in the schools: Why it isn't happening. Journal of Technology and Teacher Education, 13, 519-546.

Bell, R. L., Abd-El-Khalick, F., \& Lederman, N. G. (1998). Implicit versus explicit nature of science instruction: An explicit response to Palmquist and Finley. Journal of Research in Science Teaching, 35, 1057-1061.

Bell, R. L., Blair, L. M., Crawford, B. A., \& Lederman, N. G. (2003). Just do it? Impact of a science apprenticeship program on high school students' understandings of the nature of science and scientific inquiry. Journal of Research in Science Teaching, 40, 487-509.

Bell, R. L., Lederman, N., \& Abd-El-Khalick, F. (2000). Developing and acting upon one's conception of the nature of science: A follow-up study. Journal of Research in Science Teaching, 37, 563-581. https://doi.org/10.1002/1098-2736(200008) 37\%3A6<563\%3A\%3AAID-TEA4>3.0.CO\%3B2-N

Bell, R. L., Matkins, J. J., \& Gansneder, B. M. (2011). Impacts of contextual and explicit instruction on preservice elementary teachers' understandings of the nature of science. Journal of Research in Science Teaching, 48, 414-436.

Bell, R. L., Mulvey, B. K., \& Maeng, J. L. (2016). Outcomes of nature of science instruction along a context continuum: Preservice secondary teachers' conceptions and instructional intentions. International Journal of Science Education, 38, 493-520. https://doi.org/10.1080/09500693.2016.1151960

Beyer, C. J., \& Davis, E. A. (2008). Fostering second graders' scientific explanations: A beginning elementary teacher's knowledge, beliefs, and practice. Journal of the Learning Sciences, 17, 381-414. https://doi.org/10.1080/ 10508400802222917

Birman, B. S., Desimone, L., Porter, A. C., \& Garet, M. S. (2000). Designing professional development that works. Educational Leadership, 57(8), 28-33. 
Bogdan, R. C., \& Biklen, S. K. (1992). Qualitative research for education: An introduction to theory and methods. Boston, MA: Allyn and Bacon.

Borko, H. (2004). Professional development and teacher learning: Mapping the terrain. Educational Researcher, 33(8), 3-15.

Brand, B., \& Moore, S. (2011). Enhancing teachers' application of inquiry-based strategies using a constructivist sociocultural professional development model. International Journal of Science Education, 33, 889-913. https://doi.org/ 10.1080/09500691003739374

Bransford, J. D., Brown, A. L. \& Cocking, R. (Eds.), 2000). How people learn: Brain, mind, experience, and school. Washington: National Academy Press.

Cantrell, P., Young, S., \& Moore, A. (2003). Factors affecting science teaching efficacy of preservice elementary teachers. Journal of Science Teacher Education, 14, 177-192.

Capps, D. K., \& Crawford, B. A. (2013). Inquiry-based instruction and teaching the nature of science: Are they happening? Journal of Science Teacher Education, 24, 497-526. https://doi.org/10.1007/s10972-012-9314-z

Center of Excellence in Leadership of Learning [Cell]. (2009, June). Summary of research on project-based learning. University of Indianapolis. Retrieved from http://cell.uindy.edu/docs/PBL\%20research\%20summary.pdf

Chin, C., \& Chia, L. (2004). Problem-based learning: Using students' questions to drive knowledge construction. Science Education, 88, 707-727. https://doi.org/10.1002/sce.10144

Cleminson, A. (1990). Establishing an epistemological base for science teaching in the light of contemporary notions of the nature of science and of how children learn science. Journal of Research in Science Teaching, 27, 429-445.

Clough, M. P. (2006). Learners' response to the demands of conceptual change: Considerations for effective nature of science instruction. Science Education, 15, 463-494.

Cohen, D. K., \& Hill, H. C. (2000). Instructional policy and classroom performance: The mathematics reform in California. Teachers College Record, 102, 294-343.

Cohen, J. (1988). Statistical power analysis for the behavioral sciences (2nd ed.). Hillsdale, NJ: Lawrence Erlbaum Associates.

Costa, A. L., \& Garmston, R. J. (2002). Cognitive coaching: A foundation for renaissance schools (2nd ed.). Norwood, MA: Christopher-Gordon Publishers, Inc.

Cothran, J. H., Geiss, R. N., \& Rezba, R. J. (2000). Students and research: Practical strategies for science classrooms and competitions ( $2^{\text {nd }}$ Ed.). Dubuque, IA: Kendall Hunt Publishing.

Crawford, B. (2000). Embracing the essence of inquiry: New roles for science teachers. Journal of Research in Science Teaching, 37, 917-937.

Creswell, J. W., \& Plano Clark, V. L. (2011). Designing and conducting mixed methods research (2nd ed.). Los Angeles: SAGE Publications.

Desimone, L. M. (2009). Improving impact studies of teachers' professional development: Toward better conceptualizations and measures. Educational Researcher, 38, 181-199.

Duran, E., Ballone-Duran, L., Haney, J., \& Beltyukova, S. (2009). The impact of a professional development program integrating informal science education on early childhood teachers' self-efficacy and beliefs about inquiry-based science teaching. Journal of Elementary Science Education, 21, 53-70.

Enochs, L. G., Scharmann, L. C., \& Riggs, I. M. (1995). The relationship of pupil control to preservice elementary science teacher self-efficacy and outcome expectancy. Science Education, 79, 63-75.

Goodhew, L. M., \& Robertson, A. D. (2017). Exploring the role of content knowledge in responsive teaching. Physical Review Physics Education Research, 13(1), 010106. https://doi.org/10.1103/PhysRevPhysEducRes.13.010106

Grierson, A. L., \& Woloshyn, V. E. (2013). Walking the talk: Supporting teachers' growth with differentiated professional learning. Professional Development in Education, 39, 401-419.

Hanuscin, D., Akerson, V. L., \& Phillipson-Mower, T. (2006). Integrating nature of science instruction into a physical science content course for preservice elementary teachers: NOS views of teaching assistants. Science Education, 90, 912-935.

Herman, B. C., Clough, M. P., \& Olson, J. K. (2013). Teachers' NOS implementation practices 2-5 years after having completed an intensive science education program. Science Education, 97, 271-309.

Hmelo-Silver, C. E. (2004). Problem-based learning: What and how do students learn? Educational Psychology Review, 16, 235-266. https://doi.org/10.1023/B:EDPR.0000034022.16470.f3

Johnson, C. C. (2006). Effective professional development and change in practice: Barriers science teachers encounter and implications for reform. School Science and Mathematics, 106, 150-161. https://doi.org/10.1111/j.1949-8594.2006. tb18172.x

Johnson, C. C. (2007). Whole-school collaborative sustained professional development and science teacher changes: Signs of progress. Journal of Science Teacher Education, 18, 629-661. https://doi.org/10.1007/s10972-007-9043-x

Johnson, C. C., Kahle, J. B., \& Fargo, J. D. (2007). A study of the effect of sustained, whole-school professional development on student achievement in science. Journal of Research in Science Teaching, 44, 775-786. https://doi.org/10.1002/tea. 20149 
Kanter, D., \& Konstantopoulos, S. (2010). The impact of a project-based science curriculum on minority student achievement, attitudes, and careers: The effects of teacher content and pedagogical knowledge and inquiry-based practices. Science Education, 94, 855-887.

Kennedy, M. M. (1999). Form and substance in mathematics and science professional development. National Institute for Science Education. Madison, WI: University of Wisconsin at Madison.

Keys, C., \& Bryan, L. (2001). Coconstructing inquiry-based science with teachers: Essential research for lasting reform. Journal of Research in Science Teaching, 38, 631-645. https://doi.org/10.1002/tea.1023

Khishfe, R. (2008). The development of seventh graders' views of nature of science. Journal of Research in Science Teaching, $45,470-496$.

Knight, J. (Ed.). (2009). Coaching: Approaches and perspectives. Thousand Oaks, CA: Corwin.

Lakshmanan, A., Heath, B., Perlmutter, A., \& Elder, M. (2011). The impact of science content and professional learning communities on science teaching efficacy and standards-based instruction. Journal of Research in Science Teaching, 48, 534-551.

Lave, J., \& Wenger, E. (1991). Situated learning: Legitimate peripheral participation. Cambridge, MA: Cambridge University Press.

Lederman, J. S., Lederman, N. G., Kim, B. S., \& Ko, E. K. (2012). Teaching and learning of nature of science and scientific inquiry: Building capacity through systematic research-based professional development. In M. Khine (Ed.), Advances in the Nature of Science Research: Concepts and Methodologies. Dordrecht, The Netherlands: Springer.

Lederman, N., Abd-El-Khalick, F., Bell, R. L., \& Schwartz, R. (2002). Views of nature of science questionnaire: Toward valid and meaningful assessment of learners' conceptions of nature of science. Journal of Research in Science Teaching, 39, 497-521. https://doi.org/10.1002/tea.10034

Lederman, N. G. (1999). Teachers' understanding of NOS and classroom practice: Factors that facilitate or impede the relationship. Journal of Research in Science Teaching, 36, 916-929.

Lederman, N. G. (2007). Nature of science: Past, present, and future. In S. K. Abell \& N. G. Lederman (Eds.), Handbook of research on science education (pp. 831-880). Mahwah, NJ: Lawrence Erlbaum Associates.

Lederman, N. G., \& Lederman, J. S. (2014). Research on teaching and learning of nature of science. In N. G.Lederman \& S. K. Abell (Eds.), Handbook of research on science education (II, pp. 600-620). New York, NY: Routledge.

Lee, C. A. (2003). Self-efficacy, standards, and benchmarks as factors in teaching elementary school science. Journal of Elementary Science Education, 15, 27-56.

Lotter, C., Harwood, W. S., \& Bonner, J. J. (2007). Overcoming a learning bottleneck: Inquiry professional development for secondary science teachers. Journal of Science Teacher Education, 17, 185-216. https://doi.org/10.1007/s10972-0059002-3

Loucks-Horsley, S., \& Matsumoto, C. (1999). Research on professional development for teachers of mathematics and science: The state of the scene. School Science and Mathematics, 99, 258-271.

Loucks-Horsley, S., Stiles, K. E., Mundry, S., Love, N., \& Hewson, P. (2010). Designing professional development for teachers of mathematics and science ( $3^{\text {rd }}$ Ed.). Thousand Oaks, CA: Corwin Press.

Luft, J. A., Firestone, J. B., Wong, S. S., Ortega, I., Adams, K., \& Bang, E. (2011). Beginning secondary science teacher induction: A two-year mixed methods study. Journal of Research in Science Teaching, 48, 1199-1224.

Maeng, J. L., \& Bell, R. L. (2012). Outcomes of the Virginia Initiative for Science Teaching and Achievement (VISTA) professional development. A paper presented at the annual meeting of NARST, Indianapolis, IN.

Maeng, J. L., Bell, R. L., St. Clair, T. L., Gonczi, A. L., \& Whitworth, B. A. (2018). Supporting elementary teachers' enactment of nature of science instruction: A randomized controlled trial. International Journal of Science Education, 40, $2245-2264$. https://doi.org/10.1080/09500693.2018.1528643

Martinez, J. F., Borko, H., \& Stecher, B. M. (2012). Measuring instructional practice in science using classroom artifacts: Lessons learned from two validation studies. Journal of Research in Science Teaching, 49, 38-67.

McComas, W. F., Clough, M. P., \& Almazroa, H. (1998). NOS in science education: An introduction. Science \& Education, 7 , 511-532.

Miles, M. B., \& Huberman, A. M. (1994). Qualitative data analysis: An expanded sourcebook (2nd Ed.). Thousand Oaks: Sage Publications.

Moutinho, S., Torres, J., Fernandes, I., \& Vasconcelos, C. (2015). Problem-based learning and nature of science: A study with science teachers. Procedia-Social and Behavioral Sciences, 191, 1871-1875.

Mulholland, J., Dorman, J. P., \& Odgers, B. M. (2004). Assessment of science teaching efficacy of preservice teachers in an Australian University. Journal of Science Teacher Education, 15, 313-331.

National Research Council. (2000). Inquiry and the national science education standards: A guide for teaching and learning. Washington DC: National Academic Press.

National Research Council. (2007). Taking science to school: Learning and teaching science in grades $K$ (p. 8). Washington: National Academies Press. 
National Research Council. (2012). A framework for K-12 science education. Washington: National Academies Press.

NGSS Lead States. (2013). Next Generation Science Standards: For States, By States. Washington: The National Academies Press.

Orgill, M. (2007). Situated cognition. In G. M. Bodner \& M. Orgill (Eds.), Theoretical frameworks for research in chemistry/ science education (pp. 187-203). Upper Saddle River, NJ: Prentice Hall.

Peters, E. E. (2012). Developing content knowledge in students through explicit teaching of the nature of science: Influences of goal setting and self-monitoring. Science \& Education, 21(6), 881-898.

Ramey-Gassert, L., \& Shroyer, M. G. (1992). Enhancing science teaching self-efficacy in preservice elementary teachers. Journal of Elementary Science Teaching, 4, 26-34.

Ramey-Gassert, L., Shroyer, M. G., \& Staver, J. R. (1996). A qualitative study of factors influencing science teaching selfefficacy of elementary level teachers. Science Education, 80, 283-315.

Roehrig, G. H., \& Luft, J. A. (2004). Constraints experienced by beginning secondary science teachers in implementing scientific inquiry lessons. International Journal of Science Education, 23, 3-24.

Roth, K. J., Garnier, H. E., Chen, C., Lemmens, M., Schwille, K., \& Wickler, N. (2011). Videobased lesson analysis: Effective science PD for teacher and student learning. Journal of Research in Science Teaching, 48, 117-148. https://doi.org/10. 1002/tea.20408

Sandholtz, J. H., \& Ringstaff, C. (2014). Inspiring instructional change in elementary science: The relationship between enhanced self-efficacy and teacher practices. Journal of Science Teacher Education, 25, 729-751.

Scharmann, L. C., Smith, M. U., James, M. C., \& Jensen, M. (2005). Explicit reflective nature of science instruction: Evolution, intelligent design, and umbrellaology. Journal of Science Teacher Education, 16, 27-41. https://doi.org/10.1007/s10972005-6990-y

Schneider, R. M., Krajcik, J. S., \& Blumenfeld, P. (2005). Enacting reform-based science materials: The range of teacher enactments in reform classrooms. Journal of Research in Science Teaching, 42, 283-312.

Schwartz, R. S., Lederman, J., \& Lederman, N. G. (2008). An instrument to assess view of scientific inquiry: The VOSI questionnaire. A paper for the annual meeting of NARST, Baltimore, MD.

Schwartz, R. S., \& Lederman, N. G. (2002). "It's the nature of the beast": The influence of knowledge and intentions on learning and teaching nature of science. Journal of Research in Science Teaching, 39, 205-236.

Schwartz, R. S., Lederman, N. G., \& Crawford, B. A. (2004). Developing views of nature of science in an authentic context: An explicit approach to bridging the gap between nature of science and scientific inquiry. Science Teacher Education, 88 , 610-645.

Shavelson, R. J., \& Webb, N. M. (1991). Generalizability theory: A primer. Thousand Oaks, CA: Sage.

Songer, N., \& Linn, M. (1991). How do students' views of science influence knowledge integration? Journal of Research in Science Teaching, 28, 761-784.

Sterling, D. R. (2007). Modeling problem-based learning. Science and Children, 45(4), 50-53.

Supovitz, J. A., Mayer, D. P., \& Kahle, J. B. (2000). Promoting inquiry-based instructional practice: The longitudinal impact of professional development in the context of systemic reform. Educational Policy, 14, 331-356. https://doi.org/10.1177/ 0895904800014003001

Supovitz, J. A., \& Turner, H. M. (2000). The effects of professional development on science teaching practices and classroom culture. Journal of Research in Science Teaching, 37, 963-980. https://doi.org/10.1002/1098-2736(200011) 37:9<963::AID-TEA6>3.0.CO;2-0

Thomas, J.W. (2000). A review of research on project-based learning. Retrieved from: http://www.bie.org/index.php/site/RE/ pbl_research/29

Trygstad, P. J., Smith, P. S., Banilower, E. R., \& Nelson, M. M. (2013). The status of elementary science education: Are we ready for the next generation science standards? ChapelHill, NC: Horizon Research, Inc.

Voogt, J., Laferriere, T., Breuleux, A., Itow, R. C., Hickey, D. T., \& McKenney, S. (2015). Collaborative design as a form of professional development. Instructional Science, 43, 259-282.

\section{SUPPORTING INFORMATION}

Additional supporting information may be found online in the Supporting Information section.

How to cite this article: Maeng JL, Whitworth BA, Bell RL, Sterling DR. The effect of professional development on elementary science teachers' understanding, confidence, and classroom implementation of reform-based science instruction. Science Education. 2020;104:326-353. https://doi.org/10.1002/sce.21562 